УДК 37.018.1(430)(44)

DOI 10.11603/me.2414-5998.2019.1.10134

Н. О. Федчишин ${ }^{1}$, О. Г. Пермякова ${ }^{2}$

${ }_{1}^{1}$ ДВНЗ “Тернопільський державний медичний університет імені I. Я. Горбачевського МОЗ України”,

${ }^{2}$ Тернопільський національний педагогічний університет

імені Володимира Гнатюка

\title{
РОЛЬ РОДИНИ Й СІМЕЙНОГО ВИХОВАННЯ В ОРГАНІЗАЦІЇ ОСВІТНЬОГО ПРОЦЕСУ НІМЕЧЧИНИ І ФРАНЦІЇ: ІСТОРІЯ ТА ДОСВІД
}

\author{
N. O. Fedchyshyn ${ }^{1}$, O. H. Permyakova ${ }^{2}$ \\ ${ }^{1}$ I. Horbachevsky Ternopil State Medical University, \\ ${ }^{2}$ Volodymyr Hnatiuk Ternopil National Pedagogical University \\ THE ROLE OF FAMILY AND FAMILY EDUCATION IN THE \\ ORGANIZATION OF EDUCATIONAL PROCESS IN GERMANY AND \\ FRANCE: HISTORY AND EXPERIENCE
}

\begin{abstract}
Мета роботи - з'ясувати вплив родини й сімейного виховання на навчально-виховний процес у Німеччині та Франції в історичному аспекті.

Основна частина. Інноваційні технології не можуть замінити виховання людини, і важливість родини поступово зростає: усвідомлюється роль виховання підростаючого покоління (формування громадянина). Вивчення історичного досвіду Німеччини та Франції щодо сімейного виховання, у виховному процесі яких втілено передові ідеї європейської педагогічної думки і які займають лідерські позиції у навчально-виховному процесі, є сьогодні актуальним. 3 педагогічної точки зору на основні принципи і засади теорії шкільної організації, педагогічні спільноти Німеччини та Франції констатували першочергове право родини на виховання дитини.

Висновки. Гербартіанство забезпечило у Німеччині всі належні передумови для освітньої політики й практики, де поєднані: сімейне виховання, креативне навчання, належний відпочинок, релігійне осмислення сенсу життя. У Франції для підтримки сімей та всіх, хто займається вихованням й освітою дітей, створені асоціації сімейної освіти, які підтримуються державою та місцевими органами влади, благодійними спільнотами й чисельними партнерами.
\end{abstract}

Ключові слова: гербартіанство; сімейне виховання; родина; Німеччина; Франція; виховний процес.

The aim of the work - to determine the influence of family and family education on the educational process in Germany and France in the historical aspect.

The main body. Innovative technologies can not replace the upbringing of a person and the importance of family is gradually increasing: the role of education of younger generation (the formation of a citizen) is emphasized. The study of the historical experience of family education in Germany and France, the educational process of which expresses advanced ideas of European pedagogical thought which occupy leading positions in the educational process, is relevant today. From the pedagogical point of view, on the basis of the main principles of the school organization theory, the teaching communities of Germany and France have stated the primary right of family for child's upbringing.

Conclusions. In Germany, Herbartianism provided all the prerequisites for educational policy and practice combining family education, creative learning, proper rest, religious understanding of the meaning of life. In France, families and all those involved in upbringing and education of children have established Family Education Associations, supported by the state and local authorities, charitable communities and numerous partners in France.

Key words: Herbartianism; family education; family; Germany; France; educational process.

Вступ. Проблеми родини й сімейного виховання викликають особливе зацікавлення. Соціальна й економічна кризи помітно погіршили демографіч-

() Н. О. Федчишин, О. Г. Пермякова ну ситуацію. Родина, традиційно дуже шанована у нашій країні соціальна інституція, значною мірою втратила свою цінність. Однак важливість родини поступово зростає: усвідомлюється її роль у роз- 
витку підростаючого покоління (у родині в дитини формуються моделі майбутнього життя) і тому дуже багато залежить від батьків.

У становленні теорії та практики сімейного виховання особливе місце займає педагогічний досвід В. О. Сухомлинського. "У віці до 6-ти років розумовий розвиток, духовне життя дітей в вирішальній мірі залежить від ... елементарної педагогічної культури матері і батька, яка виражається в мудрому розумінні надзвичайно складних душевних рухів людини, яка розвивається” [4], - писав В. О. Сухомлинський. Вагомий внесок у розробку проблем сімейного виховання зробили видатні вітчизняні вчені К. Д. Ушинський, С. Ф. Русова, А. С. Макаренко, В. О. Сухомлинський, М. Г. Стельмахович, В. Г. Постовий, Т. О. Алексєєнко та інші. Вітчизняні педагоги К. Д. Ушинський, В. О. Сухомлинський, М. Г. Стельмахович дали обгрунтування сім’ї як важливого первинного природного осередку, де виховуються діти. Питання сімейного виховання та соціалізації дитини в сім’ї були завжди актуальними і залишаються предметом наукових досліджень. Так, у численних роботах вітчизняних і зарубіжних учених (Т. Алексєєнко, Ф. Ар’єс, Ю. Азаров, Ф. Байков, В. Гуров, Е. Дюркгейм, Ф. Дюбет, П. Дюрмінг, Т. Кравченко, Д. Лавеню, Ф. Лебран, К. Лелівьєвр, Ф. Майєр, М. Міщенко, Т. Поніманська, Л. Пономаренко, В. Постовий, Ж. П. Пуртуа, Ж. П’яже, Ж.-Ж. Руссо, А. Харчев, Т. Шеляг, Д. Фабле, М. Фуко й ін.) розглядаються найрізноманітніші аспекти цієї проблеми: від теоретичних проблем сім’ї до основ психолого-педагогічної культури батьків та умов ефективного сімейно-родинного виховання.

Відтак назріває необхідність пошуку зарубіжного педагогічного досвіду з окресленої проблематики, зокрема Німеччини, де яскраво втілено передові ідеї європейської педагогічної думки, які мали суттєвий вплив на становлення педагогічної науки, а відтак і Франції. Це пояснюється тим, що освітня система Франції багата на історичні освітні традиції, що обумовлювало їі провідну роль у Європі впродовж декількох останніх століть; середня школа Франції завжди вважалася “світовою дослідною ділянкою”, а система освіти в цій країні тривалий час була однією з найкращих в Європі.

Мета роботи - 3'ясувати вплив родини й сімейного виховання на навчально-виховний процес у Німеччині та Франції в історичному аспекті.

Основна частина. У зв’язку з цим цікавим для вивчення й аналізу є в історії педагогіки досвід гербартіанців (комплекс ідей, поглядів, концепцій, які відображають основні тенденції та принципи ви- ховного процесу, роль сім’ї у діяльності школи). Єдність трьох інституцій (держави, школи та церкви) були визначальними в гербартіанській педагогіці. Ф.-В. Дьорпфельд, В. Райн, К.-Ф. Стой, Й. Трюпер, Т. Ціллєр та ін. підтвердили призначення держави щодо культурного й політично-суспільного розвитку, освітніх закладів - інтелектуального розвитку, а церкви - духовного виховання. Ф.-В. Дьорпфельд доповнив таке поєднання інституцією сім’ї, оскільки саме їй належить основна виховна робота у формуванні особистості. Це означало для нього, що дана інституція не була частиною певного інтересу, а мала повне зацікавлення й охоплювала інтерес держави, школи і церкви [6]. Ф.-В. Дьорпфельд закликав до спільної діяльності всі чотири об’єднання (у поглядах на освіту, духовне життя).

В історії розвитку німецької школи Ф.-В. Дьорпфельд відмітив такі передумови: 1. Значний інтерес до шкільної освіти; 2. Зростання свідомості, батьківського обов'язку, батьківських прав та поінформованості родини щодо освіти; 3. Участь батьків в управлінні школою; 4. Соціальна та економічна свобода суспільства. Оскільки ці чотири передумови були відсутні у колишній Пруссії, Ф.-В. Дьорпфельд зазначив, що, відповідно, тут немає вільних шкільних товариств (1. На початку XIX ст. значну роль відігравав панівний клас; 2. Відсутність навичок управління в церковних товариствах; 3. Відокремлення сім’ї від держави і церкви; 4. Відсутність інтересу до шкільної освіти). Ф.-В. Дьорпфельд констатував історичне повернення до єдності держави, школи та церкви, оскільки згідно з розпорядженням мерії до ради директорів освітніх закладів відповідної місцевості входили і представники духовенства (інспектори) [6]. Відтак однією з головних його ідей було заснування родинної спілки з метою спільного виховання молоді.

Водночас важливою для гербартіанців була свобода віросповідання і відзначаємо їх рекомендації щодо лояльного ставлення, поваги і права до будьякої конфесійної приналежності, визнаної державою. Ф.-В. Дьорпфельд був переконаний, що при недостатньому виховному впливі християнської теології авторитарними методами чи неподоланим Реформацією “духом схоластики” [7] виховне значення релігійних спільнот буде незначним. Він уважав, що держава не спроможна безпосередньо впливати на розвиток теології, й сам пропонував увести вивчення богословської педагогічно спрямованої науки. Ф.-В. Дьорпфельд виходив з того, що значна кількість населення не знала основ виховання, не сповідувала моральних принципів [6] 
i якщо інституція побудована на основах віри, то і держава стоятиме на підгрунті моралі.

Для В. Райна заснування школи було пов’язане з утворенням шкільних організацій, які підтримувалися батьківським комітетом й взаємодіяли для спільного виховання дітей. Кожне шкільне співтовариство було представлене певною кількістю членів шкільної батьківської ради й мало свої етико-релігійні принципи. Протиріччя викликані несприйняттям римо-католицькою церквою шкільних спільнот. В. Райн заперечував, що сім’я мала право вибирати своїх представників для церкви, шкільних спільнот, міських громад та інших представницьких органів. На переконання гербартіанця, впродовж десятиліть протестантські громади доводили, що участь батьків у керівництві школою є “зісланим благословенням” [10]. Незважаючи на те, що значна кількість населення жила за межею бідності, проте виявляла значний інтерес до належного виховання своїх дітей. Питання не стояло, чи, по-перше, суспільство було готове до самоврядування, по-друге, чи володіли представники духовенства, мерії, вчительства необхідною кваліфікацією для системи самоврядування і які вимоги ставилися до інтелігенції.

На основі своїх спостережень за функціонуванням системи навчання та виховання у Німеччині В. Райн відмітив такі принципово важливі напрями: на противагу однобічній лінії партій, педагогіка пояснювала школу як інституцію, вільну від безпосереднього впливу держави та церкви [9]. Оскільки дві останні мали велике зацікавлення у шкільній освіті, сюди були задіяні також і сімейні та місцеві спільноти; по-друге, права і обов’язки таких чотирьох факторів, як сім’я, громадянське суспільство (місцеві об’єднання), держава та церква, слід було визначити та документально засвідчити.

3 педагогічної точки зору на основні принципи і засади теорії шкільної організації, В. Райн констатував першочергове право родини на виховання дитини. Права громадянського суспільства, держави та церкви визначав гербартіанець як непрямі, грунтуючи свої доводи на принципі сімейного виховання дитини у Й. Песталоцці, Й.-Ф. Гербарта, В. фон Гумбольдта, Шляйєрмахера, К. Магера, Ф.-В. Дьорпфельда, К.-Ф. Стоя, Й. Трюпера, Т. Ціллєра. Школу він розглядав як інституцію для навчання та виховання молоді, а шкільну спільноту як родинне товариство, яке цікавиться питаннями школи, а їх неповнолітні діти належать до етикорелігійних, громадських і політичних спілок.

Власне навчання здійснювалося за певним єдиним планом. В. Райн наполягав на важливості одна- кового світобачення, конфесійної приналежності батьків та педагогів, що було основою родинних товариств, проте без будь-якого тиску на іновірних. Водночас така школа мала визнаватися державою й дотримуватися всіх її приписів. Родини, родинні товариства могли відкривати приватні школи, які підпорядковувалися земським управлінням освіти, а відтак і державному. Офіційно визнані родинні товариства отримували корпоративні права на самоуправління. Статут такої школи мав швидше синодний характер.

Окремі родинні товариства мали шкільні ради: місцеві товариства - місцеві шкільні ради, товариства провінцій - шкільні синоди провінцій, та, відповідно, республіканські товариства - національний синод із питань школи. 3 метою успішного функціонування родинних товариств сім'ї мали певні повноваження, що забезпечувало непряме втручання держави і церкви у процес навчання. Тому держава, церква та школа складали єдиний організм взаємодопомоги, взаємопроникнення і підтримки.

Релігійні конфесії визнавали самостійність шкільних організацій й не мали права у будь-який час втручатися в освітній процес (навчальний план, викладання релігії в школі). Шкільний синод натомість надавав можливість представникам конфесій вносити корективи у вибір підручників, методичних матеріалів тощо. Така школа зовнішньо підпорядковувалася державі, а внутрішньо вибудовувалася на засадах релігійних принципів. Громадянське суспільство і державне міністерство здійснювали загальне керівництво (формування школи як інституції, майнові та грошові відносини тощо). Відтак держава не мала повноважень повністю впливати на основи і характер школи й, відповідно, на процес навчання та виховання і використовувати її для власних цілей, а вимагати від школи забезпечення повноцінного навчального та виховного процесів i виконання визначених завдань. Школа сама забезпечує методичні шляхи досягнення цих цілей. В. Райн переконував, що органи педагогічного нагляду були такі: районні шкільні установи з сімейними товариствами, провінційна шкільна рада разом із шкільним синодом, міністерство з освіти з профільною радою та синодом із питань освіти держави.

Звернення до досвіду французького виховання дітей становить для нас інтерес і, в першу чергу, це пояснюється тими негайними потребами сучасності, які вимагають вирішення і вдосконалення. Це стосується як шкільної освіти, вищої освіти, так і виховання молоді, а відтак молодших членів нашого суспільства (дітей від народження до пе- 
ріоду закінчення школи). Отже, вивчення досвіду інших країн (позитивного та негативного) завжди $\epsilon$ доброю основою для розробки власних проектів розвитку будь-якої гілки освітньої системи. Як ми зауважили, вивчення досвіду Франції є беззаперечно корисним. Перш за все, це можна пояснити тим, що ця європейська країна завжди вважалася “світовою дослідною освітньою ділянкою”, а система освіти в цій країні тривалий час була однією з найкращих в Європі.

Розвиток педагогічної освіти у Франції пов’язаний із періодом Просвітництва, який розпочався з середини XVIII ст., а головним завданням якого було релігійно-моральне виховання. Характерними рисами у вихованні дітей до цього часу були ідеї схоластичного вчення та муштра. Представники Просвітництва впроваджували у виховання гуманістичні традиції, які полягали в тому, що особистість повинна реалізувати свої природні права людини, кожен має право на здобуття освіти, а вихованню, як і освіті, належить вирішальна роль у становленні особистості. Нові підходи до виховання дітей були запропоновані Ж.-Ж. Руссо (ідеї виховання нової людини). Суть нової теорії, яка була запропонована Ж.-Ж. Руссо, полягала в природовідповідності, тобто виховання дитини повинно відповідати віку дитини і впроваджуватися на лоні природи, що допоможе дитині позбутися будь-якого шкідливого впливу. До того ж відкидалися будь-які покарання зі сторони дорослих та неприпустимими були авторитаризм у вихованні, сліпе підкорення дітей наказам дорослих. Головне завдання виховання Ж.-Ж. Руссо вбачав у тому, щоб виховати людину, яка була б вільною, жила зі своєї праці, цінувала право інших людей, вміла захищати свободу. Він висловив думку, як і згодом гербартіанці, що кожна дитина переходить у своєму розвитку через певні ступені (фази), які вихователь мусить брати до уваги і не переступати їх, поки дитина не дозріє до кожного з них. Виховання має відбуватися серед природних умов, охоплювати фізичну, духовну та моральну сторони дитини [3].

Оновлення теорії і практики виховання й освіти відбулося після Французької революції (17891794), яка наклала відбиток на всі сфери суспільного життя і в інших країнах Європи. Ідеї французького Просвітництва знайшли своє відображення в запропонованих проектах оновлення системи освіти: (проект Ш. Талейрана (1791) - система державних шкіл, загальність і безоплатність початкового навчання; проект Ж. Кондорсе (1793) обов’язковість і безоплатність навчання, рівна державна освіта для молоді обох статей, відміна релігії як навчальної дисципліни; проект Л. Лепелетьє (1793) - план національного республіканського виховання, створення суспільних виховних закладів інтернатного типу з повним самообслуговуванням, обов'язковість виховання і державного утримання дітей від 5 до 12 років). Однак лише окремі їх риси реалізовані в освітніх системах різних європейських країн [2].

У першій половині XX ст. намітилися дві основні парадигми - педагогічний традиціоналізм, орієнтований, перш за все, на філософське осмислення процесу виховання та освіти (Е. Дюркгейм, Ж. Маритен та ін.), та реформаторська педагогіка, що зосереджується на особистості дитини, її вікових та індивідуальних особливостях (А. Біне, С. Френе тощо).

Вивчення наукових джерел та їх аналіз дають нам підстави стверджувати, що Франція є єдиною країною серед одинадцяти країн, у яких проводилося дослідження, де матері проводять найменше часу зі своїми дітьми. Перш за все, це пов’язано з тим, що після народження дитини матері-француженки довго не залишаються у відпустці для догляду за дитиною. Адже француженки цінують свою роботу, бояться її втратити. Отож працююча мама у Франції-це норма. В країні створені всі умови для поєднання материнства та професійної діяльності жінок. У пріоритеті громадська думка активно підтримує працюючу жінку, а держава допомагає у вихованні дітей. Тому в країні так багато муніципальних дошкільних закладів, які і займаються вихованням дітей дошкільного віку.

У Франції для підтримки сімей та всіх тих, хто займається вихованням та освітою маленьких дітей, створені асоціації сімейної освіти. Ця діяльність підтримується державою та місцевими органами влади, а також різноманітними благодійниками та чисельними партнерами. Всі структури, які пов’язані з раннім вихованням дитини, а це і педіатри, і яслі (crèche), і дошкільні заклади раннього виховання дітей (maternelle) є невід’ємними елементами єдиного механізму раннього виховання дитини, частинами цієї єдиної структури [8].

Варто зауважити, що сім'я у Франції залишається основою освіти, що, насамперед, стосується виховання. Про це свідчать результати проведеного у Франції опитування для видання “La Croix”. Дослідження показало, що у Франції є “традиційне” розподілення освітніх ролей. За даними цього дослідження, 77 \% французів вважають, що школа, передусім, - це “місце для навчання базових знань” і лише 9 \% опитаних вважають основною місією школи навчити правил життя в суспільстві [5]. 
Згідно з дослідженнями, більшість респондентів вважає, що саме сім’я відіграє важливу роль у підготовці до громадянства (це вважають 61 \% опитуваних), а 80 \% респондентів дотримуються думки, що правил поведінки та життя в суспільстві можна навчитися в сім'ї, отримати навички здорового способу життя можна також лише в сім’ї (95 \%) [5]. На нашу думку, варто зазначити цікавий феномен, який виявлено по завершенні даного дослідження. При опитуванні французів отримано такі результати: коли французів просять визначити людину, яка мала на них найсильніший виховний вплив у дитинстві, то перші три показники відносяться до сімейного кола: бабусі і дідусі (8 \%), гроші батьків (22 \%), мати (53 \%). У Франції виховання залишається справою матерів. Отже, вочевидь, представлені результати опитування свідчать про те, що громадяни Франції пріоритетне значення у вихованні надають сім'ї.

Однак, незважаючи на велику зайнятість батьків і раннє виховання дітей в колективах дитячих установ, батьки контролюють життя дитини і привчають її з ранніх років до дисципліни. Вони прагнуть формувати у дитини повагу до чужої власності, розкривають ії індивідуальні задатки, привчають до дисципліни.

Під час свого перебування у Франції, проживши деякий час у французьких сім'ях, стає вочевидь зрозумілим, наскільки деякі підходи у вихованні дітей відрізняються від того, як українські батьки піклуються про дітей. Зовсім не можна говорити, що в когось краще, а в когось гірше налагоджений цей ланцюжок “батьки - діти”. Особливо цікавим $є$ спостереження і порівняння реакції українських дітей, інколи і здивування від того, як вибудовуються взаємостосунки між дітьми і дорослими, зокрема в родині. Вже з самого дитинства маленькі члени суспільства у Франції є співрозмовниками і вміють поводитися в товаристві.

Звичайно, є різні сім'ї і в кожній сім'ї існують свої правила. Однак загальних правил поведінки французи привчають своїх дітей дотримуватися з раннього дитинства. Дітей з раннього віку навчають вітатися чи то при зустрічі, чи коли приходиш будькуди, дякувати, спокійно поводитися в очікуванні в черзі чи в громадському транспорті. “Мистецтво жити разом” - важливий критерій взаємовідношень у французькому суспільстві. Тому соціальні навички дитини завжди вважаються чимось важливим та позитивним.

Зазвичай діти у Франції дотримуються режиму. Це стосується і прийому їжі, і виконання домашніх завдань (якщо це школяр), і чітко знають час, коли можуть займатися своїми улюбленими справами, або просто гратися, гуляти. Французькі діти з самого раннього віку добре розуміють, що в сім'ї батьки - головні, і з такими переконаннями зростають й чітко виконують розпорядження батьків, не вступають з ними в суперечки. У плані виховання $є$ різні ідеї, але загалом найбільш проявленою є тенденція до того, щоби не дозволяти дітям перетворюватися на “центр всесвіту”, “королів”, яким все можна і яким дозволено псувати життя своєму оточенню. Проте французькі діти відчувають, що їх люблять і піклуються про них. Отже, французькі методи у вихованні маленьких дітей спрямовані на розвиток у дітей таких навичок, як ввічливість, уміння їсти за столом, їсти разом з іншими, поважати інших, терпіння, що вважаються чимось важливим та позитивним - адже французи, як ми уже зазначали вище, дуже цінують “мистецтво жити разом”.

Звичайно, $є$ і винятки з цього правила, але це не так часто зустрінеш у французькому суспільстві. Правила виховання у французьких сім'ях $є$ непохитними й існують впродовж тривалого часу. Стосовно традицій французького виховання дітей, то, перш за все, необхідно зазначити, що дітей вчать бути відповідальними і слухняними людьми, з яких повинні вийти добропорядні сім'янини і громадяни своєї країни.

Висновки. Отож наприкінці XIX ст. основи гербартіанства зазнали особливо гострої критики, в першу чергу, в Німеччині. Невдоволення пояснювалося двома причинами: для вчителів школи XIX ст. гербартіанська педагогіка виявилася недостатньо пристосованою, а для педагогів-реформаторів XX ст. сконцентрованою на особі вчителя, схематичною.

Узагальнюючи теоретичні здобутки гербартіанців, відзначаємо усвідомлення зростаючої потреби щодо використання основ національного виховання, зокрема пропозиції щодо уведення до навчального плану дитячого садка народних легенд, німецьких казок. Гербартіанці визначили мету виховання на релігійних засадах, що не сприяло привабливості їх педагогіки, оскільки релігійний аспект поєднав у гербартіанській педагогіці дві суперечливі тенденції педагогіки XIX ст.: християнство й науковість. Гербартіанство забезпечило у Німеччині всі належні передумови для освітньої політики й практики, де поєднані: сімейне виховання, креативне навчання, належний відпочинок, релігійне осмислення сенсу життя.

Вивчення наукових і літературних джерел дає нам підстави стверджувати, що хоча у Франції добре 
розвинена структура дитячого виховання, а громадська думка активно підтримує працюючу жінку, держава допомагає у вихованні дітей, однак пріоритети у вихованні дітей французи надають сім’ї. Французькі методи у вихованні дітей направлені на

\section{Список літератури}

1. Державна сімейна політика в країнах Західної Європи [Електронний ресурс]. - Режим доступу : http://shev. gov.ua/index.php? option=com_content\&task=view\&id= 6882\&Itemid=479.

2. Коменский Я. А., Локк Д., Руссо Ж.Ж., Песталоцци И. Г. Педагогическое наследие / [сост. В. М. Кларин, А. Н. Джуринский]. - М. : Педагогика, 1987. - 416 с.

3. Салига Н. Історія дошкільної педагогіки : навч.метод. посіб. до курсу / Н. Салига. - Івано-Франківськ : HAIP, 2014. - 120 с.

4. Сухомлинський В. О. Батьківська педагогіка / В. О. Сухомлинський [Електронний ресурс]. - Режим доступу : http://teacher.at.ua/publ/v_o_sukhomlinskij_ batkivska_pedagogika/38-1-0-5089.

5. Denis Peiron. Pour les Français, la famille estl'acteur clé de l'éducation [Електронний ресурс]. - URL : https://www. la-croix.com/Famille/Education/Pour-Francais-famillelacteur-leducation-2016-11-06-1200801163.

6. Dörpfeld F. W. Die freie Schulgemeinde und ihre Anstalten auf dem Boden der freien Kirche im freien Staate.

\section{References}

1. Derzhavna simeina polityka v krainakh Zakhidnoi Yevropy [State family policy in Western European countries]. Retrieved from: http://shev.gov.ua/index.php? option=com_content\&task=view\&id=6882\&Itemid=479 [in Ukrainian].

2. Klaryn, V.M., \& Dzhurynskyy, A.N. (Comp.). (1987). Komenskyi Ya.A., Lokk D., Russo Zh.-Zh., Pestalotsy I.G. Pedagogicheskoe nasledye [Komenskyi Ya.A., Lokk D., Russo Zh.-Zh., Pestalotsy I.G. Pedagogical heritage]. Moscow: Pedagogika [in Russian].

3. Salyha, N. (2014). Istoriia doshkilnoi pedahohiky: navchalno-metodychnyi posibnyk do kursu [History of pre-school pedagogy: study guide to the course]. IvanoFrankivsk: NAIR [in Ukrainian].

4. Sukhomlynskyi, V.O. Batkivska pedahohika [Parent pedagogy]. Retrieved from: http://teacher.at.ua/publ/v_o_ sukhomlinskij_batkivska_pedagogika/38-1-0-5089 [in Ukrainian].

5. Denis, Peiron. Pour les Français, la famille estl'acteur clé de l'éducation. Retrieved from: https://www.la-croix. com/Famille/Education/Pour-Francais-famille-lacteur-led ucation-2016-11-06-1200801163. розвиток навичок і вмінь, які в подальшому дозволяють добре себе почувати в суспільстві і дотримуватися правил суспільного життя. “Мистецтво жити разом” - важливий критерій взаємовідношень у французькому суспільстві.

Beiträge zur Theorie des Schulwesens / F. W. Dörpfeld. Gütersloh : C. Bertelsmann, 1863. - 346 S.

7. Dörpfeld F. W. Ein Beitrag zur Leidensgeschichte der Volksschule nebst Vorschlägen zur Reform der Schulverwaltung / F. W. Dörpfeld. - Gütersloh : C. Bertelsmann. 4. Aufl.; 1899. - 371 S.

8. Education et accueil des jeunes enfants. Rapport préalable à la visite des experts en France., mai 2003. OCDE [Electronic resource]. - URL : http://www.oecd.org/ fr/education/scolaire/34402477.pdf.

9. Rein W. Pädagogik in systematischer Darstellung / W. Rein. - 3. Bd. C. : Methodologie. Die Lehre von den Mitteln der Erziehung.2. Aufl. - Beyer \& Söhne, Langensalza, 1912. - $361 \mathrm{~S}$.

10. Rein W. Theorie und Praxis des Volksschulunterrichts nach Herbartschen Grundsätzen. Ein theoretisch-praktischer Lehrgang für Lehrer und Lehrerinnen sowie zum Gebrauch in Seminaren / W. Rein, Pickel, EduardScheller. 4 Bde. [4 Bde in einem Buch]. - 2. Aufl. - Dresden : Bleyl\&Kaemmerer, 1881. - 732 S.

6. Dörpfeld, F.W. (1863). Die freie Schulgemeinde und ihre Anstalten auf dem Boden der freien Kirche im freien Staate. Beiträge zur Theorie des Schulwesens. Gütersloh: C. Bertelsmann.

7. Dörpfeld, F.W. (1899). Ein Beitrag zur Leidensgeschichte der Volksschule nebst Vorschlägen zur Reform der Schulverwaltung. C. Bertelsmann. 4. Aufl.

8. Education et accueil des jeunes enfants. Rapport préalable à la visite des experts en France., mai 2003. OCDE. Retrieved from: http://www.oecd.org/fr/education/ scolaire/34402477.pdf.

9. Rein, W. (1912). Pädagogik in systematischer Darstellung. 3. Bd. C.: Methodologie. Die Lehre von den Mitteln der Erziehung.2. Aufl. Beyer \& Söhne, Langensalza.

10. Rein, W., Pickel, \& EduardScheller (1881). Theorie und Praxis des Volksschulunterrichts nach Herbartschen Grundsätzen. Ein theoretisch-praktischer Lehrgang für Lehrer und Lehrerinnen sowie zum Gebrauch in Seminaren. 4 Bde. [4 Bde in einem Buch]. 2. Aufl. Dresden: Bleyl\&Kaemmerer. 